\title{
Observations on the Biology and Anatomy of Myerslopiidae (Hemiptera, Membracoidea)
}

\author{
Roman Rakitov \\ Paleontological Institute, Profsoyuznaya Street 123, Moscow 117647, Russia \\ Correspondence should be addressed to Roman Rakitov; rakitov@gmail.com
}

Received 29 September 2015; Revised 29 October 2015; Accepted 1 November 2015

Academic Editor: Ai-Ping Liang

Copyright ( 2015 Roman Rakitov. This is an open access article distributed under the Creative Commons Attribution License, which permits unrestricted use, distribution, and reproduction in any medium, provided the original work is properly cited.

\begin{abstract}
Adults and nymphs of Mapuchea chilensis (Nielson), from the poorly known family Myerslopiidae, were collected from the litter horizon of temperate forests and shrub bogs in southern Chile. The species apparently feeds on roots and creeping stems of angiosperms. Salivary sheaths of captive specimens terminated in vascular bundles. Indirect evidence suggests feeding on phloem sap. Both nymphs and adults are strong jumpers and both actively disperse, as evidenced by their capture in pan traps. The Malpighian tubules of this species produce no brochosomes and, unlike in most previously studied Membracoidea, comprise no specialized secretory segment. Each tubule comprises secretory cells scattered among excretory ones, a condition not previously known among Hemiptera.
\end{abstract}

\section{Introduction}

The family Myerslopiidae includes three genera, two in New Zealand and one in Chile, altogether containing 19 morphologically similar species [1]. Adult myerslopiids are stout, strongly sclerotized insects, 3 to $7.5 \mathrm{~mm}$ in length, with elytralike, medially sealed tegmina, and without traces of hind wings underneath. Both adults and nymphs dwell cryptically on or near the ground, and their integument, sculptured with ridges and protuberances, is usually camouflaged with hardened soil (Figures $1(\mathrm{a})-1(\mathrm{~h})$ ). Members of the family have formerly been classified as a tribe within the leafhopper subfamily Ulopinae (Cicadellidae) but more recently were recognized as a sister lineage to the rest of Membracoidea (leafhoppers + treehoppers), which shares some plesiomorphic traits with cicadoids and cercopoids [2]. The disjunct range of the group has been interpreted as evidence of its considerable age and association with Gondwanaland $[1,2]$.

Until now the main sources of information on the myerslopiids biology were collecting records of the New Zealand species, the majority of which described the habitat as simply "moss" or "litter" [3]. This led Hamilton to assume that myerslopiids, like peloridiids, are "associated with moss rather than with higher plants." Bryophagy has not been known in Cicadomorpha and is exceptionally rare among other
Auchenorrhyncha [4]. Other authors referred to myerslopiids as possible fungivores [1] or even predators [5]. The life history of myerslopiids thus merits clarification.

Also of interest is the activity of the Malpighian tubules of myerslopiids. Secretions of these organs play important roles in the biology of different groups of Cicadomorpha [68]. For example, cicadellids actively coat their integuments with water-repellent sheaths of brochosomes, proteinaceous products of specialized Malpighian tubule segments [9-12]. It has been argued that the production of brochosomes had evolved in the common ancestor of Membracoidea [13]. Because myerslopiids have been identified as being among the few leafhopper taxa lacking brochosomes [14], data on their Malpighian tubules are much needed.

An expedition to temperate Chile during the austral summer of 2013-2014 gave the author an opportunity to clarify the microhabitat of myerslopiids, observe behaviors of captive specimens, and preserve material for anatomical studies. A note on the myerslopiids karyotype and tests has already been published [15]. Here, I present ecological, behavioral, and anatomical observations to demonstrate that myerslopiids present no significant departures from cicadellids in their life history traits, but their Malpighian tubules have a different organization, not previously known among Hemiptera. 


\section{Methods}

Collecting was done mostly by manual sorting of detritus on a white plastic sheet. At the Senda Darwin biological station, additional specimens were collected in water-filled white or yellow disposable plastic dishes placed on the ground as pan traps. Most of the collected specimens were kept live in ventilated plastic food containers on plant cuttings, moss, rotten wood, and detritus from the source microhabitat. Their behaviors were intermittently observed under a stereomicroscope.

Adults and nymphs collected at Senda Darwin were caged on cuttings of Griselinia racemosa roots, identified as a likely food source. To examine salivary sheaths, roots segments where the insects had been observed feeding were marked with a pen marker and then excised, fixed in $4 \%$ formaldehyde for 24 hours, and stored in $70 \%$ ethanol. These root chunks were subsequently embedded into paraffin, cut into $5 \mu \mathrm{m}$ sections, and stained with hematoxylin and eosin.

The ultrastructure of the Malpighian tubules was examined in two adult females, one adult male, and two 3rdinstar nymphs. The specimens were preserved in $2.5 \%$ glutaraldehyde in PBS buffer, pH 7.4. The tubules were dissected out, stained with osmium tetroxide, embedded in Epon, and sectioned into $60 \mathrm{~nm}$ sections. The sections were poststained with uranyl acetate and lead citrate and examined on a JEM1011 transmission electron microscope (JEOL Ltd., Japan).

\section{Results}

3.1. Collected Material. Chile: Huerquehue National Park, $\mathrm{N}$ of Lake Tinquilco, head of the Lagos trail, $39.155^{\circ} \mathrm{S}$, $71.716^{\circ} \mathrm{W}$, mature Nothofagus forest with Chusquea understory (Figure 2(a)), 20-25 Dec., 2013, 10 adults and 5 nymphs from leaf litter with Hydrangea serratifolia, Dendroligotrichum dendroides, and small ferns (Figure 2(b)); same site, 9-10 Feb., 2014, 11 adults and 1 nymph (2nd instar). Puyehue National Park, sector Anticura, near park entrance, $200 \mathrm{~m} \mathrm{~N}$ of Road $215,40.667^{\circ} \mathrm{S}, 72.174^{\circ} \mathrm{W}, 15-17$ Jan., 2014, $>25$ adults and 5 nymphs (5th instar) from ca. $3 \mathrm{~m}^{2}$ of leaf litter under a tree, with abundant Hydrangea serratifolia and some herbaceous plants (Figures 2(c)-2(e)); trail Princesa, $40.665^{\circ} \mathrm{S}, 72.172^{\circ} \mathrm{W}, 15$ Jan., 2014, 3 nymphs (5th instar) from forest leaf litter along trail; trail Chile, $40.669^{\circ} \mathrm{S}, 72.170^{\circ} \mathrm{W}$, 18 Jan., 2014, 2 adults and 1 nymph (5th instar) from forest leaf litter with Blechnum, Hydrangea, and Dendroligotrichum; trail Salto del Indio, mature Nothofagus forest, 19 Jan., 2014, 4 adults from leaf litter. Alerce Andino National Park, sector Sargazo, near park entrance, $41.508^{\circ} \mathrm{S}, 72.621^{\circ} \mathrm{W}$, open slope near forest edge, 6 Jan., 2014, 1 nymph (5th instar) from short grass and moss under Drimys; the same site, Drimys forest with Chusquea, 8 Jan., 2014, 2 adults from litter with Dendroligotrichum and creeping vines. Chiloé, Senda Darwin biological station, forest, postfire bog with abundant shrubs (Baccharis, Tepualia, and Gaultheria), large ferns (Blechnum spp., Gleichenia squamulosa), and trees (Figures 2(f) and 2(g)), 41.88 $\mathrm{S}, 73.67^{\circ} \mathrm{W}, 11$ Jan., 2014, 3 nymphs (2nd and 3rd instars) from inside the spongy mass of decomposing old fronds around "trunks" of large Blechnum magellanicum; the same site, 27 Dec., 2013-4 Jan., 2014, 6 nymphs (5th instar) from accumulation of litter and peat under Podocarpus and large ferns, with abundant Griselinia racemosa roots; the same site, 13 Jan., 2014, and 1-7 Feb., 2014, 5 adults and 6 nymphs (4th and 5th instars), captured in plastic pan traps (Figure 2(g)), mostly on rainy nights. Chiloé National Park, sector Cucao, shrub bog along the Lahuan trail (Figure 2(h)), $42.621^{\circ} \mathrm{S}, 74.107^{\circ} \mathrm{W}, 13$ Jan., 2014, 1 nymph (5th instar) from peat with roots; the same site, 3 Feb., 2014, 2 adults from litter and detritus under large ferns and trees; sector Rancho Grande, $42.572^{\circ} \mathrm{S}, 74.075^{\circ} \mathrm{W}, 3$ Feb., 2014,1 nymph from moss, coll. V. Hartung.

The specimens varied in size, sculpturing, and coloration between and within the collecting sites but were all assigned to Mapuchea chilensis (Nielson). The type locality of that first South American myerslopiid to be described is in the Anticura sector of the Puyehue NP [5]. Szwedo [16] made it the type of his genus Mapuchea, in which he described two additional species, each based on a single specimen: $M$. burckhardti, from Bosque de Fray Jorge NP, which is the northernmost outpost of Valdivian temperate rain forests, and $M$. hamiltoni from the Huerquehue NP. The specimens I collected in the Huerquehue NP did not consistently differ from the specimens collected elsewhere.

3.2. Observations of Caged Insects. Due to their cryptic habitat and camouflage, the insects could not be observed in nature. Caged adults and nymphs survived indefinitely until killed. They walked slowly but most of the time clung motionlessly to plant stems or roots, occasionally expelling droplets of clear excrement, which was interpreted as a sign of feeding. The insects were not observed feeding or staying long on green plant parts but twice were observed feeding on damp rotten wood. When disturbed, both nymphs and adults jumped strongly. In one adult, a jumping distance of $50 \mathrm{~cm}$ was recorded. The jumps ended by crash-landing followed by brief immobility. Two captive 5th instar nymphs molted to the adult stage. One of these (Figure 1(c)) was closely watched for 9 hours following the molt, during which it remained inactive. No attempts to coat the integument with soil or plant debris were noticed in either of molted specimens during the days following the molt. Grooming, courting, and mating were not observed.

3.3. Salivary Sheaths. Seven salivary sheaths were tracked, all of them terminating in the vascular bundle of the rootlet. Among these, two penetrated into the xylem (Figures 3(a) and $3(\mathrm{~b})$ ), while the rest were difficult to interpret, terminating equivocally between the phloem and the xylem (Figures $3(\mathrm{c})$ and $3(\mathrm{~d})$ ) or being poorly preserved. One branched sheath was observed (Figure 3(a)).

3.4. Malpighian Tubules. The general arrangement of the digestive tract and four Malpighian tubules is as typical for Cicadomorpha (Figure 4). The shape of the Malpighian tubules is identical in adults and nymphs. Each tubule gradually widens towards the base but becomes constricted again for a short length before entering the filter chamber. 


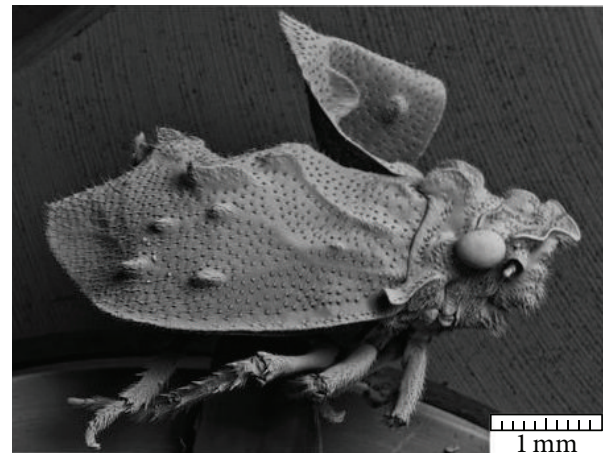

(a)

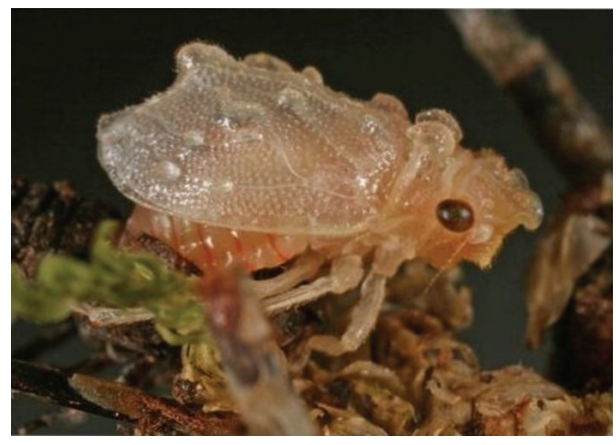

(c)

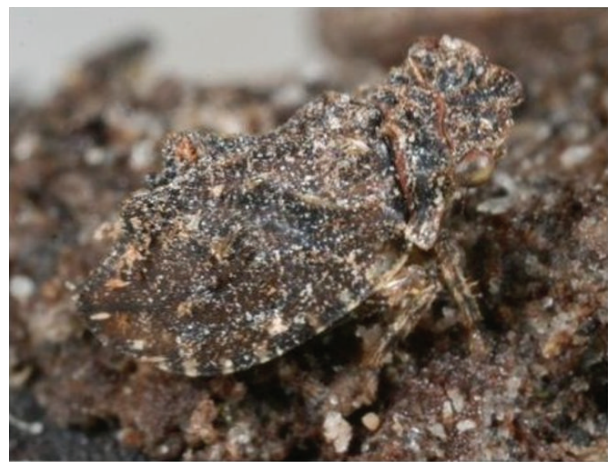

(e)

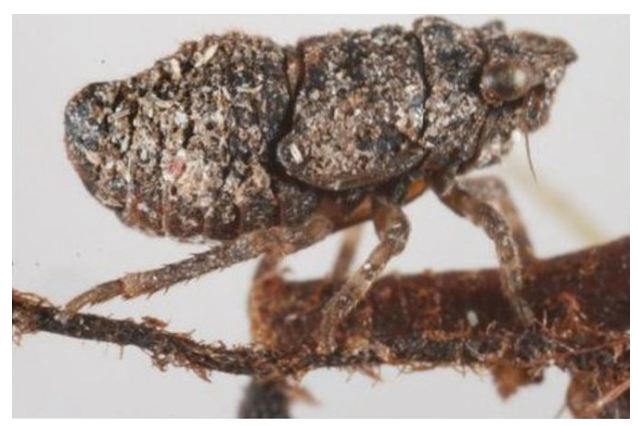

(g)

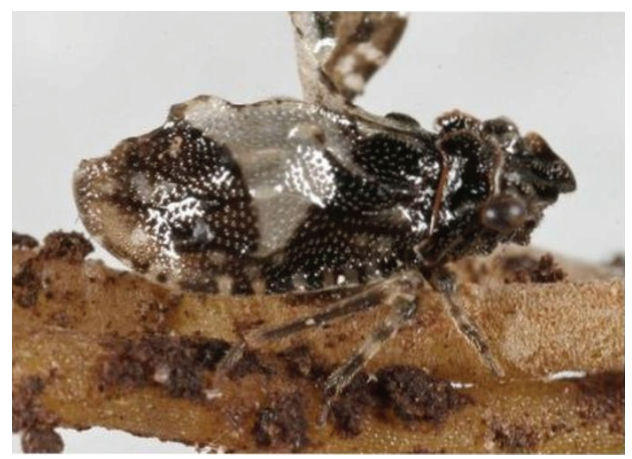

(b)

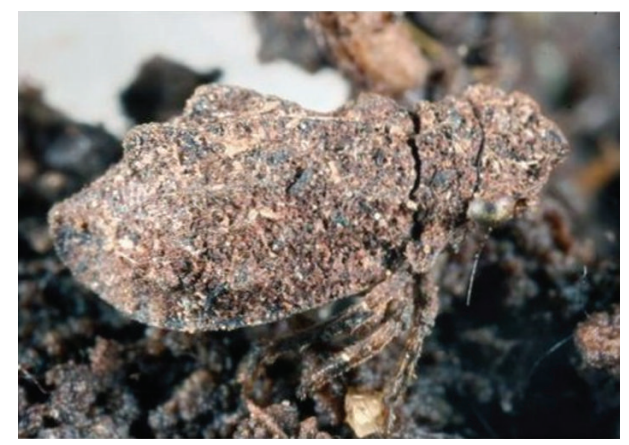

(d)

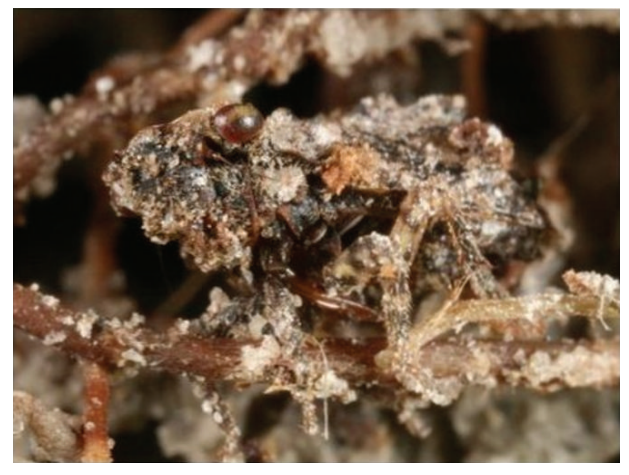

(f)

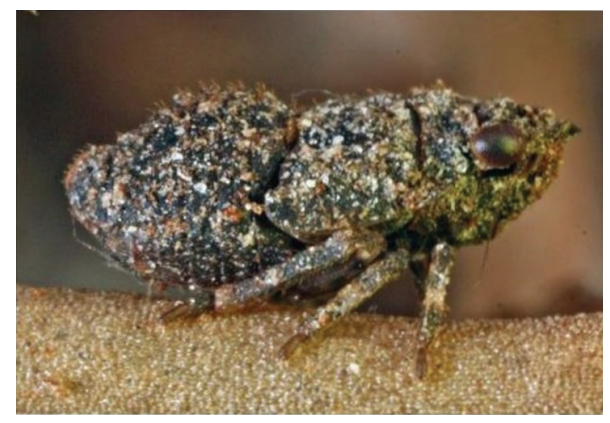

(h)

Figure 1: Mapuchea chilensis. ((a), (b), (c), and (d)) Specimens from the Huerquehue NP. (a) Scanning electron image of a female molted in captivity and not camouflaged with soil; the left tegmen is mangled. (b) The same specimen live, showing color pattern. (c) Freshly molted female. (d) Camouflaged specimen. (e) Specimen from the Puyehue NP. (f) Soil camouflage in combination with disruptive coloration of legs makes this specimen hard to see; note that the eyes remain clean. (g) 5th instar nymph. (h) 3rd instar nymph. All photos of live specimens were taken in captivity. 


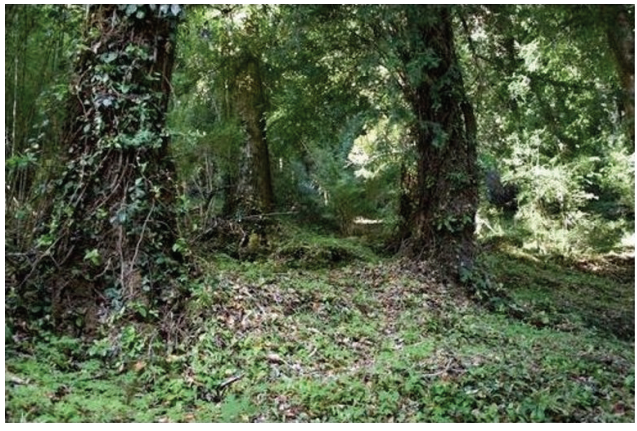

(a)

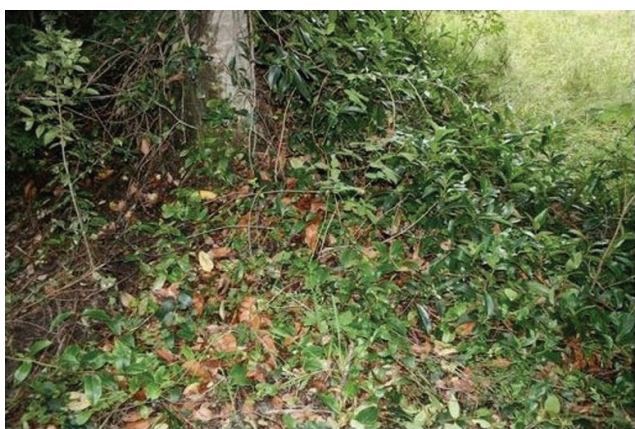

(c)

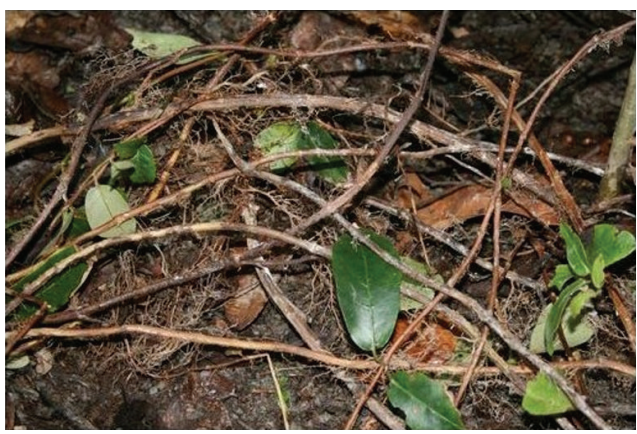

(e)

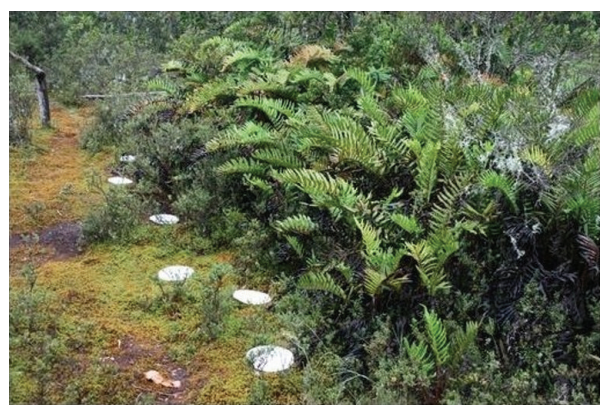

(g)

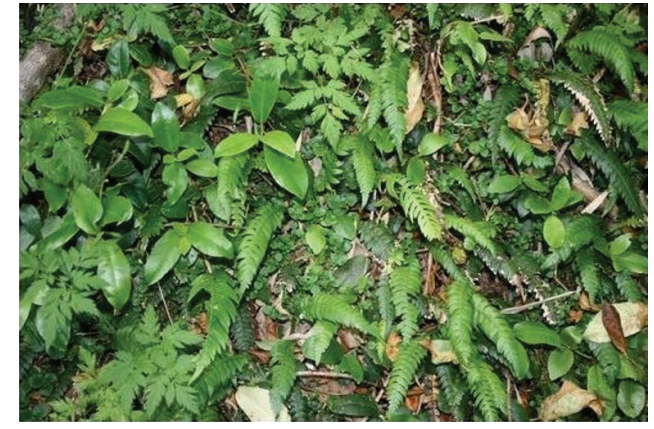

(b)



(d)

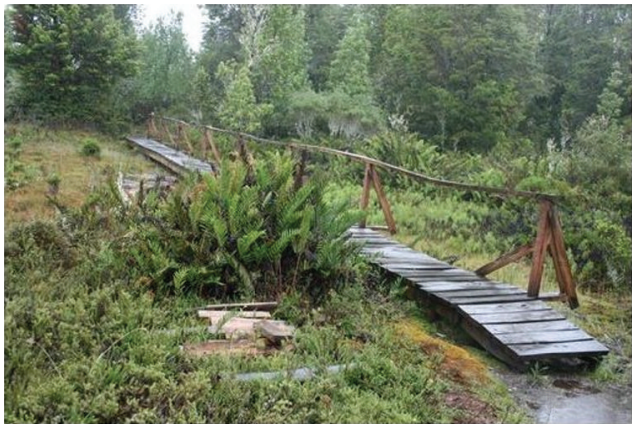

(f)

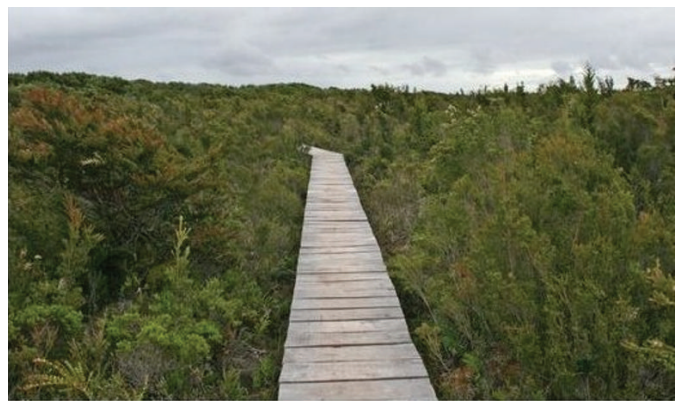

(h)

Figure 2: Mapuchea chilensis habitats (collecting sites). (a) Nothofagus forest $\mathrm{N}$ of the lake Tinquilco in Huerquehue NP. (b) The same forest floor with ferns and Hydrangea sp. (c) Puyehue NP near Anticura campground, leaf litter near a tree base, with abundant Hydrangea serratifolia. (d) The same, detailed view; note the absence of mosses and ferns. (e) The same, with litter removed to expose creeping stems of H. serratifolia; also note the abundant volcanic ash deposited upon the 2011 Puyehue-Cordón Caulle eruption. (f) Shrub bog at the biological station Senda Darwin on Chiloé. (g) The same, showing pan traps. (h) Shrub bog in Chiloe NP near Cucao. 


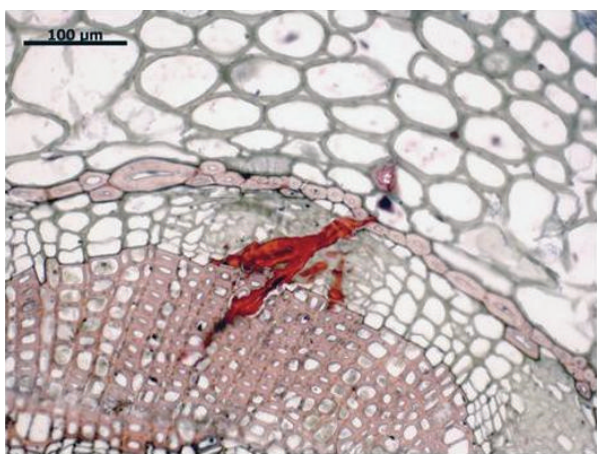

(a)

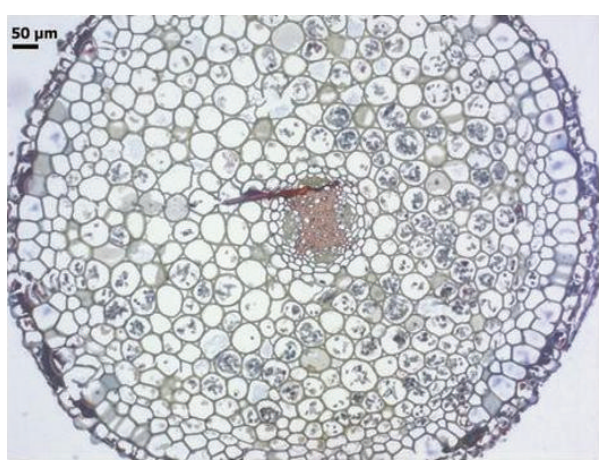

(c)

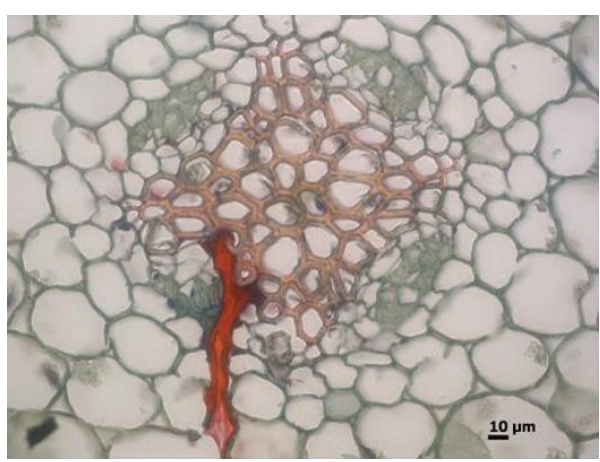

(b)



(d)

FIGURE 3: Histological sections of Griselinia racemosa roots with salivary sheaths of Mapuchea chilensis. (a) Branched sheath, with one branch penetrating into the xylem. (b) Sheath terminating in the outermost layer of the xylem. ((c) and (d)) Sheath terminating equivocally, between the phloem and the xylem.

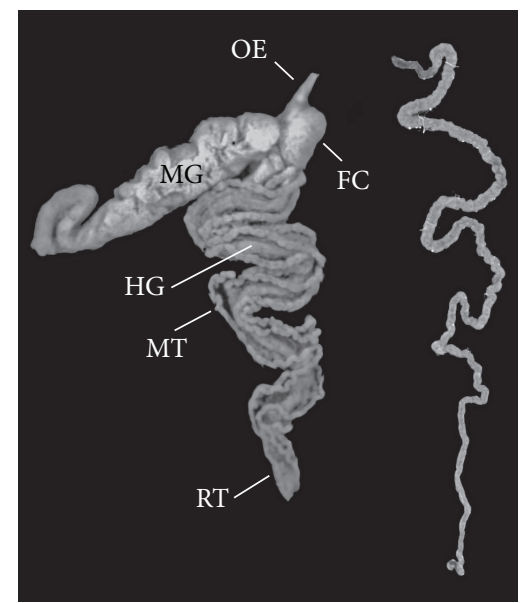

FIgURE 4: Mapuchea chilensis digestive tract with the Malpighian tubules and an isolated tubule (omitting the basal part entering the filter chamber). OE: oesophagus; FC: filter chamber; MG: midgut; MT: Malpighian tubules; and RT: rectum.

The exposed length of the tubule is convoluted and nodulose, resembling twisted rope, distally less so (Figure 4). The tubules form two pairs, the termini of each pair united in a loop attached to the rectum.
In both nymphs and adults, the exposed parts of the tubules comprise two types of cells, excretory and secretory. In the thicker, more basal part of the tubule, secretory cells are interspersed among more numerous excretory cells. As the tubule narrows distally, the secretory cells gradually disappear; the most distal part seemingly comprises only excretory cells.

The excretory cells have an extensively developed labyrinth of basal membrane infoldings (Figures 5(a) and 5(b)). Their apical membrane bears a brush of long, simple, or lamellar microvilli, containing mitochondria, and forms intracellular canaliculi, some of them branching or forming flask-shaped cavities (Figures 5(b) and 5(c)). These cavities are also lined with microvilli or lamellae (Figure 5(d); compare with Figure 8 in [17]). The cytoplasm contains numerous conspicuous mitochondria and, in some cells, deposits of glycogen granules (Figure 5(d); compare with [18]).

The secretory cells (Figures 6(a)-6(h)) are smaller and lack apical microvilli and conspicuous mitochondria. They contain numerous secretory vacuoles filled with spherical or somewhat irregular dense granules, ca. $0.2 \mu \mathrm{m}$ in diameter, with coarsely granulose surface (Figure 6(f)), and, occasionally, smaller particulate material. The $0.2 \mu \mathrm{m}$ granules are also present in the tubule lumen (Figure 6(c)). The granules are formed in Golgi cisternae (Figures 6(g) and 6(h)). Most of the remaining cytoplasm is filled with cisternae of endoplasmic 


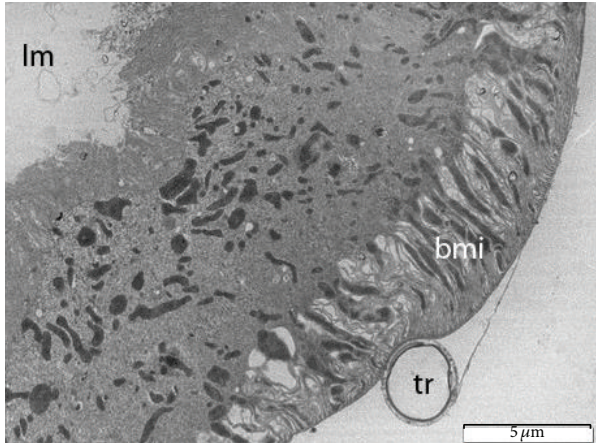

(a)

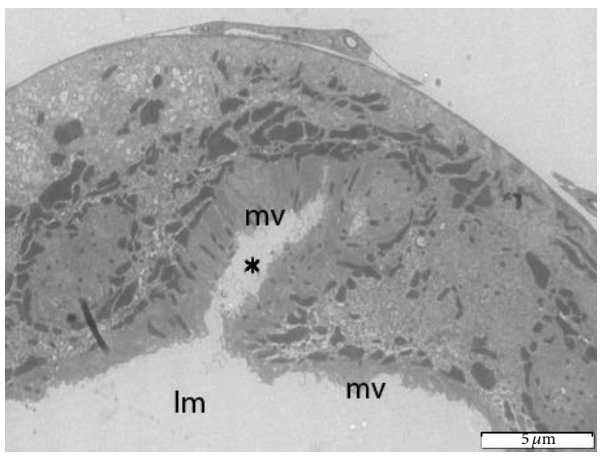

(c)

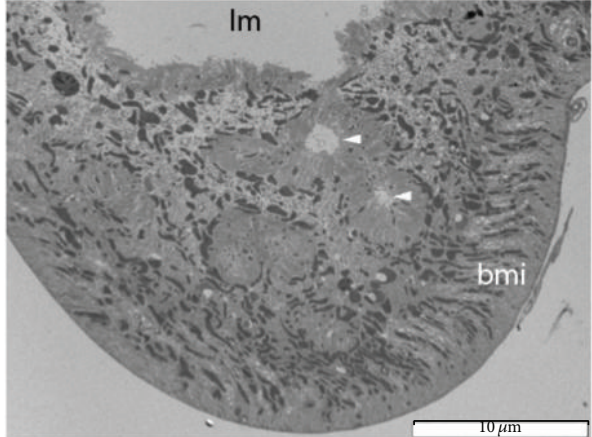

(b)

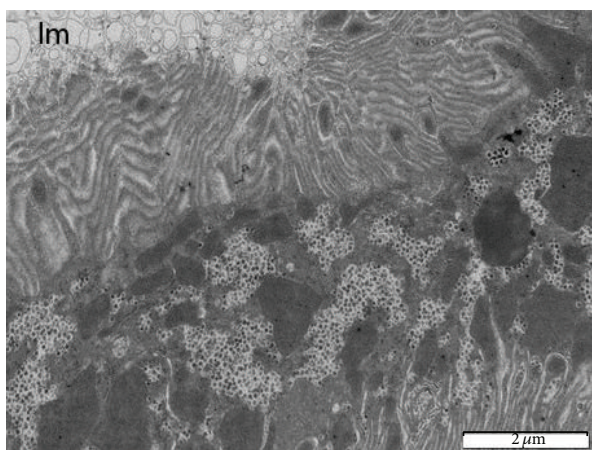

(d)

Figure 5: Excretory cells of the Malpighian tubules of Mapuchea chilensis. ((a)-(c)) Adult insects, general structure of the cells. (d) 3rd instar nymph, an excretory cell showing deposits of granular glycogen and lamellar microvilli bordering an intracellular canaliculus. $1 \mathrm{~m}$ : tubule lumen; tr: trachea; and bmi: basal membrane infoldings. Intracellular canaliculi are shown with arrowheads in (b) and an asterisk in (c).

reticulum containing homogeneous material (Figure 6(d), arrowheads).

\section{Discussion}

4.1. Habitats and Hosts. M. chilensis was collected in temperate Chile from forests and shrub bogs. This is similar to the New Zealand myerslopiids, which also occur in both forested and open habitats [3]. M. chilensis dwells cryptically on the ground or within decomposing plant material. On bogs, where the litter horizon is not well defined, the insect can be found at considerable depths within the peat. Most of the microhabitats where $M$. chilensis was found contained roots or stems of angiosperms, which apparently served as the food source. At several forest locations in the Huerquehue, Puyehue, and Alerce Andino parks, the insects were found between creeping stems of the vine Hydrangea serratifolia. It grew abundantly at the site in Anticura where the largest numbers of $M$. chilensis, 30 specimens, were collected (Figures 2(c)-2(e)). In at least two sites on the bog at Senda Darwin (Figure 2(f)), M. chilensis appeared to be associated with surface roots of the shrub Griselinia racemosa, abundantly ramifying within the litter and peat. Interestingly, like myerslopiids, the genus Griselinia has a disjunct distribution between southern South America and New Zealand. Caged insects were observed feeding on both G. racemosa roots
(Figures 3(a)-3(d)) and H. serratifolia stems. No single plant species was present at every collecting site, indicating that M. chilensis is not associated with one host, but all such sites contained angiosperms. Most of the previous records did not associate myerslopiids with angiosperms, although three New Zealand species have been collected, among other places, from Celmisia and mats of Raoulia, both of Asteraceae [3]. Ferns were present at most of the collecting sites (Figures 2(b) and 2(g)) but were absent from the Anticura site (Figures 2(c)-2(e)). Curiously, three nymphs were found within dead plant material coating the "trunks" of large ferns that microhabitat could potentially contain epiphytes. A single record of a New Zealand myerslopiid from a fern has been listed [3].

Previous records consistently associated myerslopiids with mosses [3]; yet mosses were completely absent from the Mapuchea-rich site in Anticura (Figures 2(c)-2(e)). The mosses on the bogs of Chiloé (Figures 2(f)-2(h)) were intensively sampled, yielding abundant peloridiids ([19]; V. Hartung, personal communication), but only occasional individuals of $M$. chilensis. The latter species was consistently found on those same bogs in moss-free detritus accumulated under shrubs, large ferns, and trees.

4.2. Feeding Mode. Salivary sheaths revealed that the insects fed by tapping into the vascular tissue. This feeding mode is consistent with the presence of a filter chamber and general 


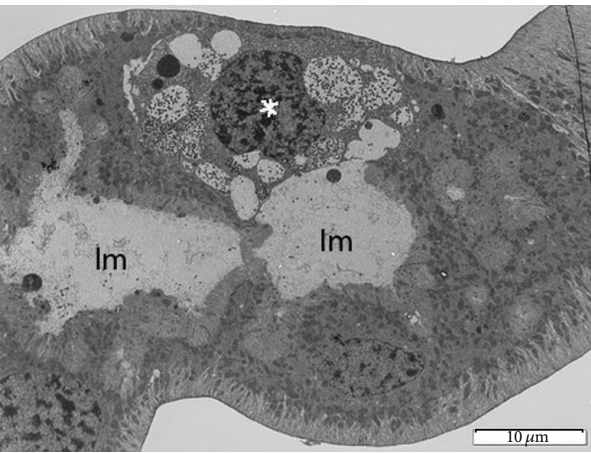

(a)

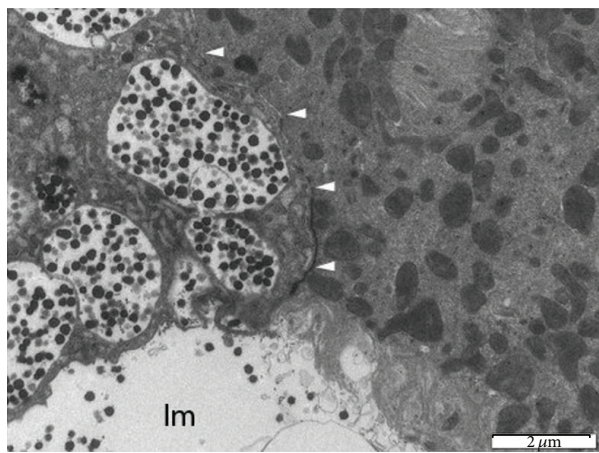

(c)

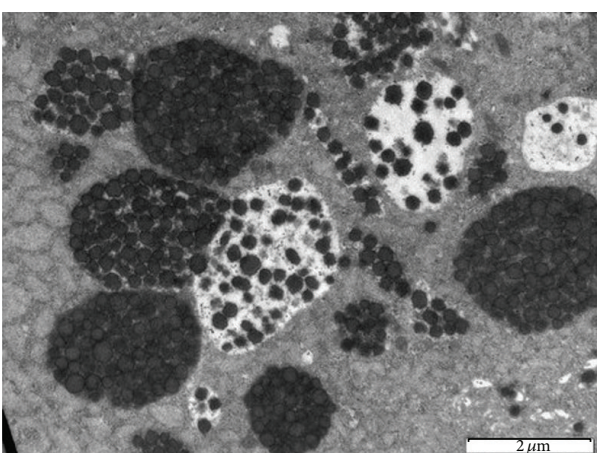

(e)

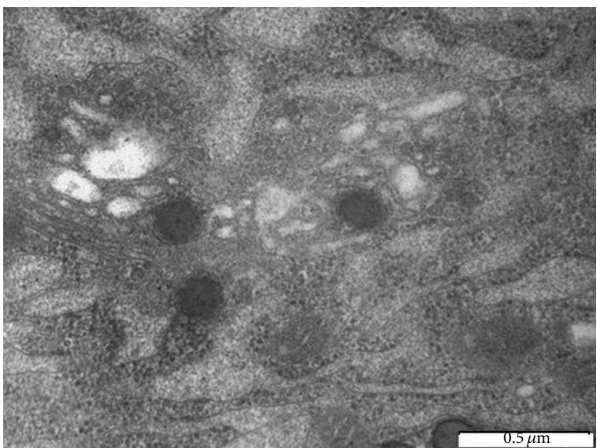

(g)

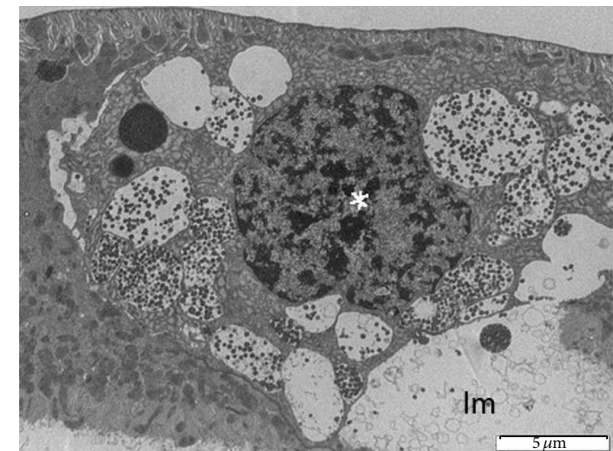

(b)

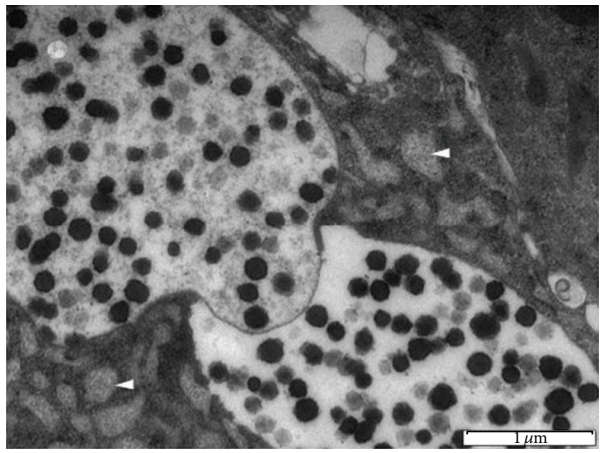

(d)

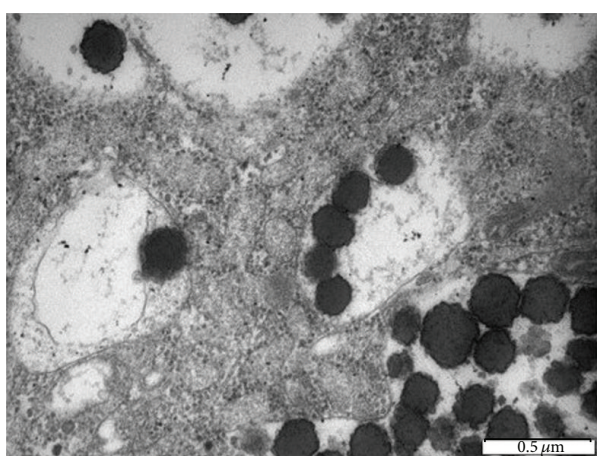

(f)

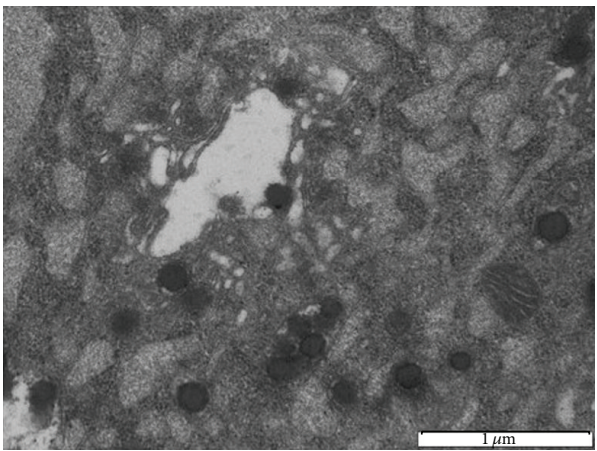

(h)

FIGURE 6: Secretory cells in the Malpighian tubules of Mapuchea chilensis. ((a)-(d)) Cells in the tubules of a 3rd instar nymph. (a) A single secretory cell (its nucleus marked by an asterisk) among excretory cells. (b) The same cell, closeup. (c) Contact between a secretory and an excretory cell; arrowheads point at the junction. Note secretory granules in the tubule lumen. (d) Secretory vacuoles with granules and additional particulate material. Arrowheads point at cisternae of endoplasmic reticulum. ((e)-(h)) Cells in the tubules of an adult. (e), (f) Secretory vacuoles variably loaded with granules. (g), (h) Golgi regions with developing granules. lm: tubule lumen. 
structure of the gut and Malpighian tubules, similar to those in previously studied Cicadomorpha (Figure 4). However, the exact source of the ingested sap, phloem or xylem, could not be identified based on the sheaths because of the small size of the sample. Salivary sheaths mark not only feeding, but also probing behavior, thus requiring many observations in order to make inferences. For example, among the 389 examined salivary sheaths of Philaenus spumarius (L.) examined by Horsefield, only $60 \%$ terminated in the xylem [20].

Although some of the observed salivary sheaths terminated in the xylem (Figures 3(a) and 3(b)), the external morphology of myerslopiids indicates xylem-feeding to be unlikely. The low nutritional value of xylem sap requires xylem-feeders to intensify ingestion by increasing the volume of cibarial pump muscles [21]. Externally this is manifested in the frontoclypeus being disproportionally enlarged in all stages, but especially so in young instars. The head proportions of myerslopiids follow the opposite developmental trajectory, with the frontoclypeus becoming progressively more inflated towards the adult stage (Figures $1(\mathrm{a})$ and $1(\mathrm{~h})$; also mentioned in [16]). Therefore, the most likely food source is phloem sap.

4.3. Locomotion and Other Behaviors. While adults jump in all the Cicadomorpha except cicadas, nymphal jumping is thought to have evolved in the ancestral membracoids and been subsequently lost in the lineage that includes several leafhopper subfamilies and treehoppers [13]. The evidence of jumping by both adult and immature Mapuchea is, therefore, not surprising. It is worth mentioning that the leafhopper subfamily Ulopinae, to which myerslopiids have been assigned in the past, contains Ulopa species with nonjumping nymphs.

The fact that adults and nymphs of $M$. chilensis were consistently captured in pan traps (Figure 2(g)) suggested that they emerged to the surface in order to disperse. The insects quickly drown because their integument is not waterrepellent. Climbing or accidentally falling from vegetation into these traps was unlikely, suggesting that the trapped insects had been moving around by hopping.

The origin of the characteristic soil crust of myerslopiids remains a mystery. Its consistent presence on the majority of collected specimens (Figures $1(\mathrm{~d})-1(\mathrm{~h})$ ) suggests that it may be actively produced, but my limited observations did not discover any such behavior. Similar crusts have been reported for the leafhopper genera Evansiola China and Paulianiana Evans, formerly allied with myerslopiines within Ulopinae [22].

4.4. Malpighian Tubules. It has long been known that the Malpighian tubules of Membracoidea are unique among Hemiptera in having, in their middle or somewhat more distally, a glandular segment [23]. It is usually inflated throughout the life cycle, but in adults of some leafhoppers it becomes secondarily deflated. This segment has been observed in all the previously examined Cicadellidae (e.g., $[23,24])$, Membracidae ([23, 24], Rakitov unpublished), and
Melizoderidae (Rakitov, unpublished), but not in Aetalionidae (Rakitov, unpublished). The glandular segment consists entirely of specialized secretory cells and is flanked on either side with narrow, nodulose tubule segments consisting entirely of excretory cells [17]. In most adult cicadellids, the secretory cells produce brochosomes, proteinaceous particles of curious structure, which are released after molts and applied in special behaviors onto the integuments (reviewed in [11]). In some cicadellid subfamilies, the glandular segments secrete brochosomes starting from the 1st nymphal instar, while in others they produce other diverse products prior to switching, during the last nymphal instar, to production of brochosomes. These Malpighian tubule secretions of leafhopper nymphs include granules, tubules, or colloids [25]. Their chemistry and function are unknown, but some leafhopper nymphs apply these secretions onto their bodies [26]. Similar products have been found in the glandular regions of the immature and adult Membracidae and Melizoderidae (Rakitov, unpublished). It has been argued that treehoppers have evolved from within leafhoppers and quit secreting brochosomes secondarily [13].

Unlike in most previously studied Membracoidea, the Malpighian tubules of $M$. chilensis have no glandular segment composed of secretory cells (Figure 4). Instead, the tubules of both nymphs and adults have secretory cells interspersed among excretory cells along the length of tubule, except in the terminal region. The secretory cells produce simple granules, ca. $0.2 \mu \mathrm{m}$ in diameter, which accumulate in large numbers in secretory vacuoles prior to being released into the lumen (Figures 6(a)-6(f)). This resembles the granular secretions produced in the Malpighian tubules of some cicadellid nymphs prior to switching to the production of brochosomes [25]. In both cases, the granules form in Golgi cisternae (Figures 6(g) and 6(h)), suggesting their proteinaceous nature. In the absence of chemical data, it is impossible to conclude whether the secretory products of $M$. chilensis are related to those of cicadellid nymphs, but this seems to be a possibility, given their structural similarity and the fact that Myerslopiidae and Cicadellidae are close relatives. The tubule excretory cells of $M$. chilensis (Figures 5(a)-5(d)) are identical to those of cicadellids [17] and represent a generic type common among insects. Therefore, the essential difference between $M$. chilensis and the previously studied Membracoidea concerns how the secretory cells are situated along the tubule: interspersed in the first case and forming a compact zone in the second.

Interspersed secretory cells, of unknown function, have been observed in the Malpighian tubules in other insect orders [27] but, to the best of my knowledge, not in Hemiptera. The closest living relatives of Membracoidea are spittlebugs (Cercopoidea) and cicadas (Cicadoidea), the three groups forming together the infraorder Cicadomorpha. During the nymphal stage, the Malpighian tubules of spittlebugs and cicadas produce secretions, spittle components in the first group $[6,7,28-30]$ and the so-called anal liquid, of uncertain function, in the second [8]. In both groups, the tubules have a similar organization, representing a third type, different from that of either M. chilensis or other Membracoidea. Each has a 


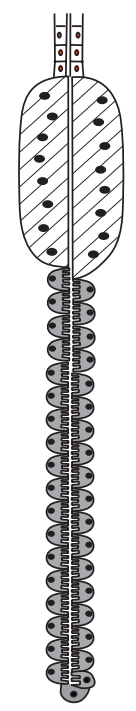

Secretory products:

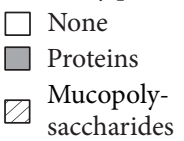

(a) (b)

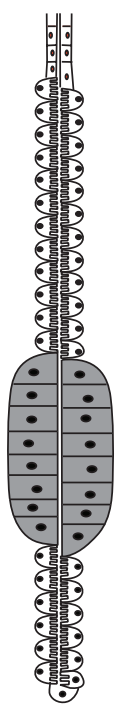

Apical microvilli and canaliculi:

$\bigcirc$ Absent

Present

(c)
Figure 7: General organization of the Malpighian tubules in Cicadomorpha. The most basal parts, hidden inside the filter chamber, are not shown. (a) Immature Cercopoidea and Cicadoidea. (b) Mapuchea chilensis. (c) Cicadellidae and Membracidae.

short inflated glandular basal segment, composed of secretory cells producing mucosubstances, and a long nodulose distal segment, composed of essentially excretory cells, with characteristic apical microvilli and intracellular canaliculi, which additionally produce proteinaceous granules $[8,28-$ 31].

The basal parts of the tubules show no secretory modification in Membracoidea, including M. chilensis, but their more distal parts secrete proteinaceous substances in all Cicadomorpha, representing three ways (Figures $7(a)-7(c)$ ) to distribute the excretory and secretory functions along the tubule: (1) cells homogenous, each combining the secretory and excretory functions (spittlebug and cicada nymphs); (2) secretory cells interspersed among excretory cells ( $M$. chilensis); and (3) excretory and secretory cells segregated into separate segments (Cicadellidae and Membracidae).

Like in M. chilensis, the Malpighian tubules of Aetalionidae have no morphologically distinct glandular region (Rakitov, unpublished), but their cell composition and ultrastructure have not yet been examined.

I have argued in the past that the secretory specializations of the Malpighian tubules together with the habit of applying their secretions onto the body, displayed by spittlebugs, cicadas, and membracoids, have a common evolutionary origin [8]. The fate of the tubule secretory products of Mapuchea is unknown; no postmolt behaviors similar to anointing of leafhoppers and treehoppers [26] was observed, but the paucity of observations makes conclusions premature.
Myerslopiidae merit further study in this regard, as they may represent the only recent group of Membracoidea which had separated prior to and thus may shed light on the origin of brochosomes and related behaviors of leafhoppers.

\section{Conflict of Interests}

The author declares that there is no conflict of interests regarding the publication of this paper.

\section{Acknowledgments}

The author thanks Dmitri Shcherbakov for organizing the expedition to Chile and taking him along, Mario Elgueta for making their field work in Chile possible, Alexander Emeljanov, Kirill Eskov, Elena Lukashevich, Elena Rodionova, Daniela Takiya, Chris Dietrich, and Victor Hartung for being supportive teammates, Yuri Zuñiga and Wladimir Silva for assistance during their stay at the biological station Senda Darwin on Chiloé, Margaret Thayer for sharing her own material and records on Mapuchea, which greatly helped planning the collecting trip, Dmitri Tishechkin for attempting to record vibrational signals of Mapuchea, and Elena Kriuchkova for preparing histological sections of roots. A permit to collect insects in the national parks was granted by the CONAF. The study was supported in part by the Russian Foundation for Basic Research Grants 13-04-01839 to Dmitri Shcherbakov and 14-04-00322 to Roman Rakitov.

\section{References}

[1] J. Szwedo, "An annotated checklist of Myerslopiidae with notes on the distribution and origin of the group (Hemiptera: Cicadomorpha)," Zootaxa, vol. 425, pp. 1-15, 2004.

[2] K. G. A. Hamilton, "The ground-dwelling leafhoppers Myerslopiidae, new family, and Sagmatiini, new tribe (Homoptera: Membracoidea)," Invertebrate Taxonomy, vol. 13, no. 2, pp. 207235, 1999.

[3] W. J. Knight, "Ulopinae of New Zealand (Homoptera: Cicadellidae)," New Zealand Journal of Science, vol. 16, pp. 971-1007, 1973.

[4] A. G. Wheeler Jr., "Bryophagy in the Auchenorrhyncha: seasonal history and habits of a moss specialist, Javesella opaca (Beamer) (Fulgoroidea: Delphacidae)," Proceedings of the Entomological Society of Washington, vol. 105, no. 3, pp. 599-610, 2003.

[5] M. W. Nielson, "A new species of Myerslopia from Chile (Homoptera: Cicadellidae)," Entomological News, vol. 107, no. 5, pp. 322-326, 1996.

[6] P. Pesson, "Sécretion d'une mucoprotéine par les tubes de Malpighi des larves de Cercopides. Son rôle dans la formation de l'abri spumeux," Bollettino del Laboratorio di Zoologia Generale e Agraria della Facoltà Agraria in Portici, vol. 33, pp. 341349, 1956.

[7] K. Kato, "The origin and composition of the cuckoo spit," The Science Reports of the Saitama University Series B, vol. 3, pp. 3353, 1958.

[8] R. A. Rakitov, "Structure and function of the Malpighian tubules, and related behaviors in juvenile Cicadas: evidence 
of homology with spittlebugs (Hemiptera: Cicadoidea \& Cercopoidea)," Zoologischer Anzeiger, vol. 241, no. 2, pp. 117-130, 2002.

[9] M. F. Day and M. Briggs, "The origin and structure of brochosomes," Journal of Ultrasructure Research, vol. 2, no. 2, pp. 239$244,1958$.

[10] J. Gouranton and P.-L. Maillet, "Origine et structure des brochosomes," Journal de Microscopie, vol. 6, pp. 53-64, 1967.

[11] R. A. Rakitov, "Brochosomal coatings of the integument of leafhoppers (Hemiptera, Cicadellidae)," in Functional Surfaces in Biology, S. N. Gorb, Ed., vol. 1, pp. 113-137, Springer Netherlands, Dordrecht, The Netherlands, 2009.

[12] R. Rakitov and S. N. Gorb, "Brochosomes protect leafhoppers (Insecta, Hemiptera, Cicadellidae) from sticky exudates," Journal of the Royal Society Interface, vol. 10, no. 87, 2013.

[13] C. H. Dietrich, R. A. Rakitov, J. L. Holmes, and W. C. Black, "Phylogeny of the major lineages of Membracoidea (Insecta: Hemiptera: Cicadomorpha) based on $28 \mathrm{~S}$ rDNA sequences," Molecular Phylogenetics and Evolution, vol. 18, no. 2, pp. 293305, 2001.

[14] R. A. Rakitov, "On differentiation of cicadellid leg chaetotaxy (Homoptera: Auchenorrhyncha: Membracoidea)," Russian Entomological Journal, vol. 6, no. 3-4, pp. 7-27, 1997.

[15] N. Golub, V. Kuznetsova, and R. Rakitov, "First karyotype data on the family Myerslopiidae (Hemiptera, Auchenorrhyncha, Cicadomorpha)," Comparative Cytogenetics, vol. 8, no. 4, pp. 293-300, 2014.

[16] J. Szwedo, "A new genus and six new species of grounddwelling leafhoppers from Chile and New Zealand (Hemiptera: Cicadomorpha: Myerslopiidae)," Zootaxa, vol. 424, pp. 1-20, 2004.

[17] D. S. Smith and V. C. Littau, "Cellular specialization in the excretory epithelia of an insect, Macrosteles fascifrons Stål (Homoptera)," The Journal of Biophysical and Biochemical Cytology, vol. 8, no. 1, pp. 103-133, 1960.

[18] M. S. Jarial, "Fine structure of the Malpighian tubules of Chironomus larva in relation to glycogen storage and fate of hemoglobin," Tissue \& Cell, vol. 20, no. 3, pp. 355-380, 1988.

[19] D. E. Shcherbakov, "A new species of Peloridium (Hemiptera: Coleorrhyncha, Peloridiidae) from Chile," Far Eastern Entomologist, vol. 286, pp. 1-11, 2014.

[20] D. Horsfield, "Evidence for xylem feeding by Philaenus spumarius (L.) (Homoptera: Cercopidae)," Entomologia Experimentalis et Applicata, vol. 24, no. 1, pp. 95-99, 1978.

[21] V. Novotny and M. R. Wilson, "Why are there no small species among xylem-sucking insects?” Evolutionary Ecology, vol. 11, no. 4, pp. 419-437, 1997.

[22] J. W. Evans, "Some relict New Guinea leafhoppers and their significace in relation to the comparative morphology of the head and prothorax of the Homoptera-Auchenorrhyncha (Homoptera: Cicadellidae: Ulopinae)," Pacific Insects, vol. 10, no. 2, pp. 215-229, 1968.

[23] E. Licent, "Recherches d'anatomie et de physiologie comparées sur le tube digestif des Homoptères supérieurs," La Cellule, vol. 28, pp. 6-161, 1912.

[24] S. P. Mukharji, "The structure and histology of the alimentary canal of the Homoptera (Hemiptera-Insecta)," Indian Journal of Zootomy, vol. 2, pp. 56-121, 1961.

[25] R. A. Rakitov, "Secretory products of the Malpighian tubules of Cicadellidae (Hemiptera, Membracoidea): an ultrastructural study," International Journal of Insect Morphology and Embryology, vol. 28, no. 3, pp. 179-193, 1999.
[26] R. A. Rakitov, "Post-moulting behaviour associated with Malpighian tubule secretions in leafhoppers and treehoppers (Auchenorrhyncha: Membracoidea)," European Journal of Entomology, vol. 93, no. 2, pp. 167-184, 1996.

[27] M. A. Prado, L. M. Montuenga, A. C. Villaro, J. C. Etayo, J. M. Polak, and M. P. Sesma, "A novel granular cell type of locust Malpighian tubules: ultrastructural and immunocytochemical study," Cell \& Tissue Research, vol. 268, no. 1, pp. 123-130, 1992.

[28] A. T. Marshall, "Spittle production and tube-building by cercopoid nymphs (Homoptera). I. The cytology of the Malpighian tubules of spittle-bug nymphs," Quarterly Journal of Microscopical Science, vol. 105, pp. 257-262, 1964.

[29] A. T. Marshall, "Spittle production and tube-building by cercopoid nymphs (Homoptera). 2. The cytology and function of the granule zone of the Malpighian tubules of tube-building nymphs," Quarterly Journal of Microscopical Science, vol. 105, part 4, pp. 415-422, 1964.

[30] A. T. Marshall, "Protein synthesis and secretion by the Malpighian tubules of cercopoid larvae (Homoptera)," Journal of Insect Physiology, vol. 19, no. 12, pp. 2317-2326, 1973.

[31] Q. Li, H. Zhong, Y. Zhang, and C. Wei, "Comparative morphology of the distal segments of Malpighian tubules in cicadas and spittlebugs, with reference to their functions and evolutionary indications to Cicadomorpha (Hemiptera: Auchenorrhyncha)," Zoologischer Anzeiger, vol. 258, pp. 54-68, 2015. 

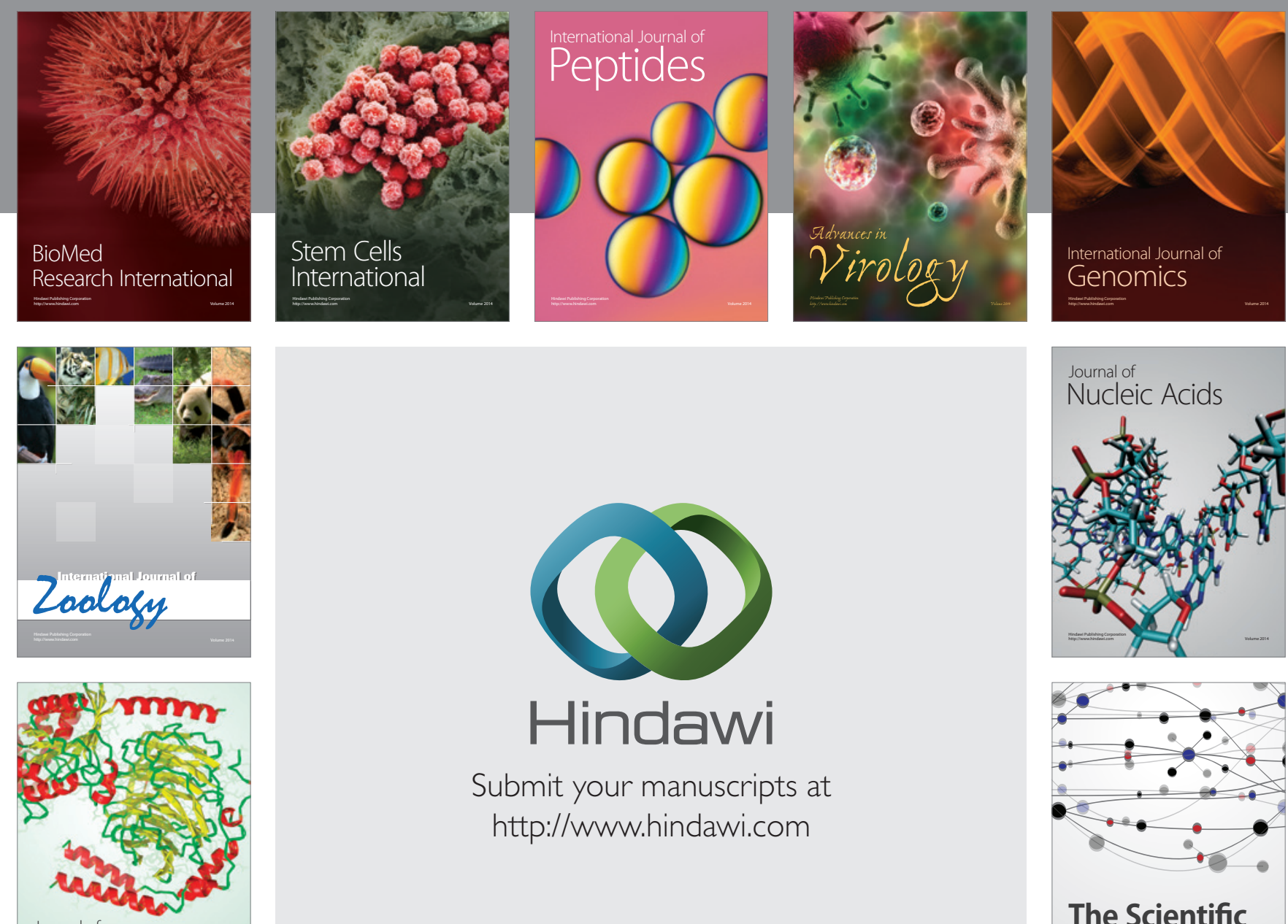

Submit your manuscripts at

http://www.hindawi.com

Journal of
Signal Transduction
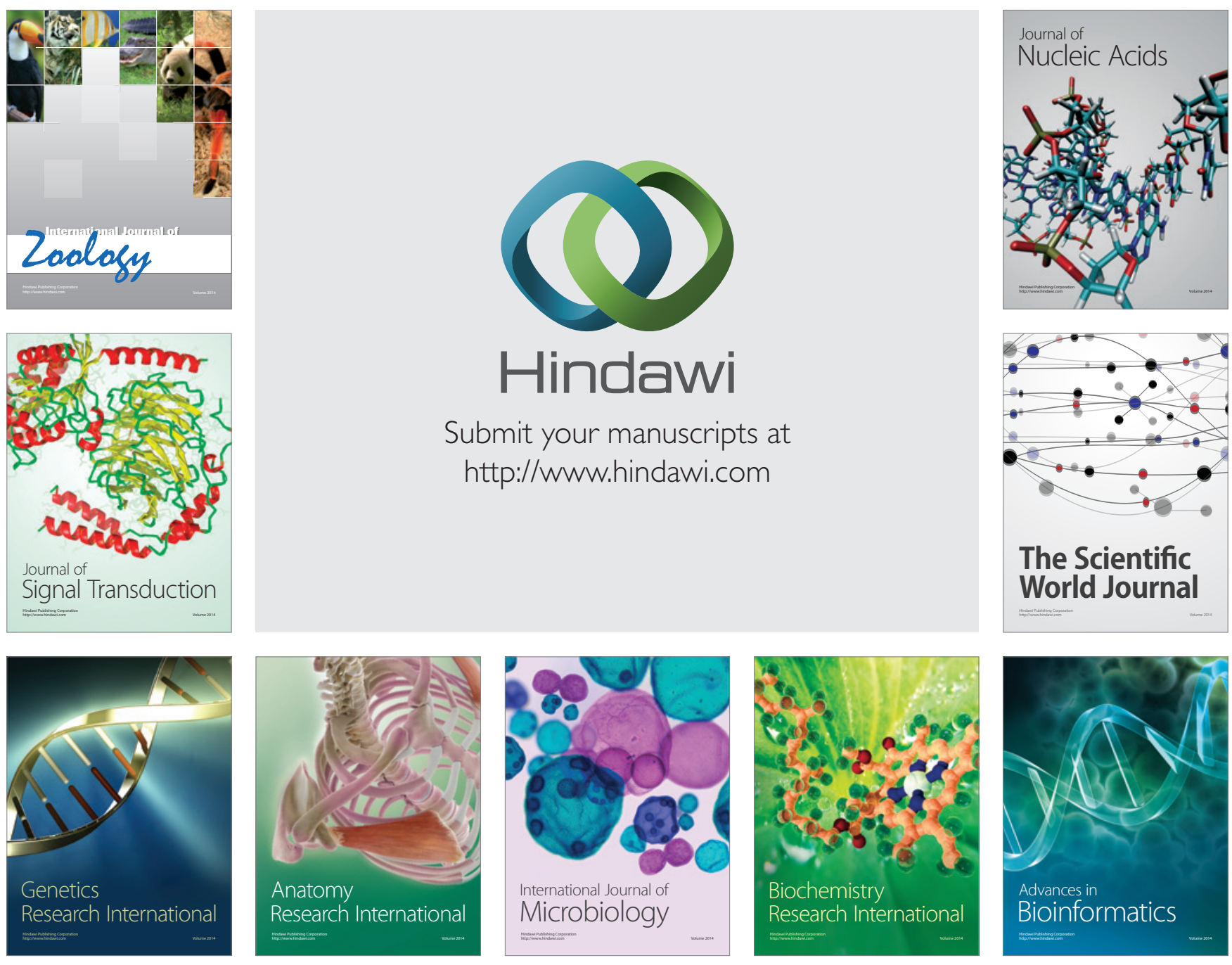

The Scientific World Journal
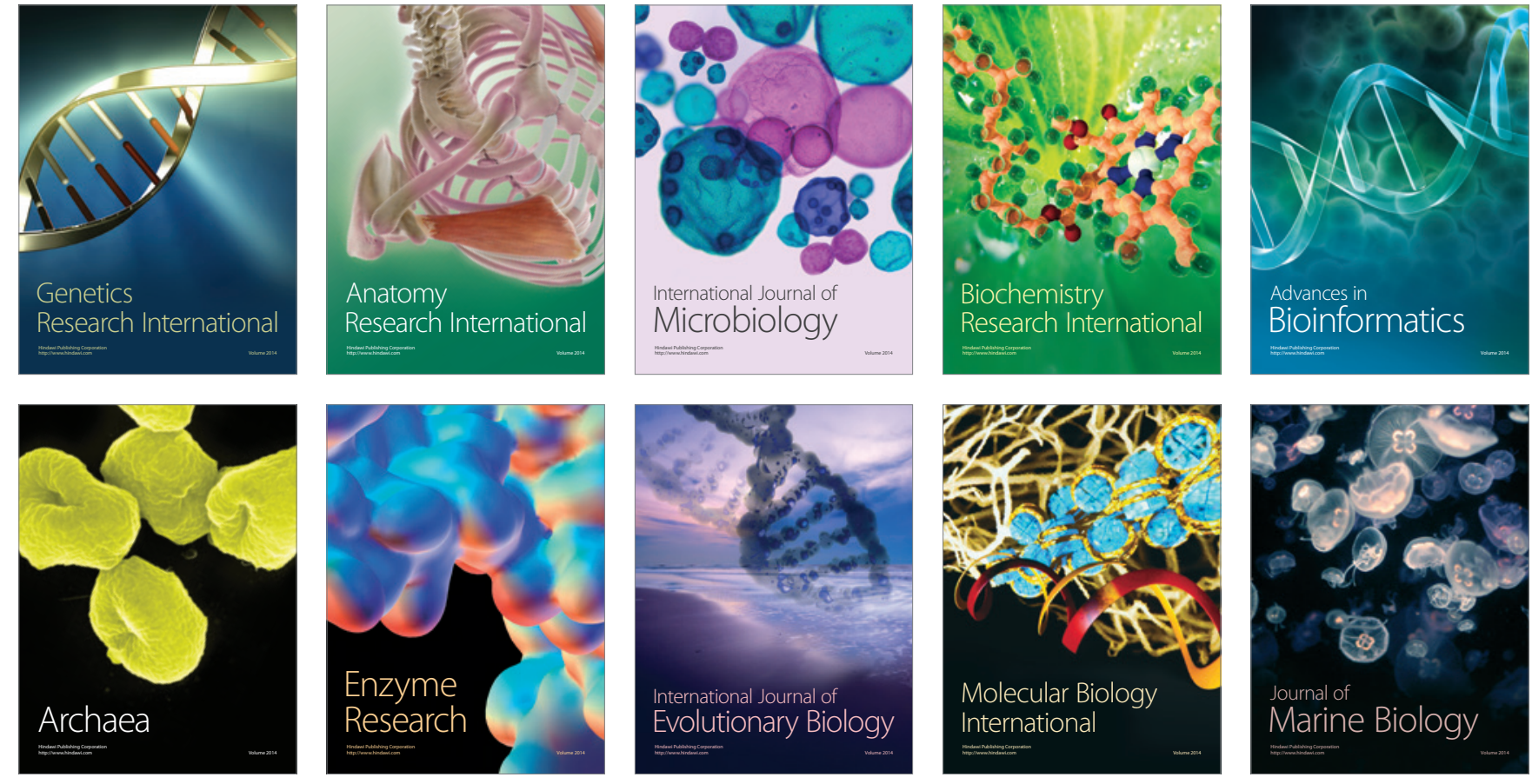